\title{
Pemanfaatan Probiotik untuk Budidaya Perikanan
}

\author{
Fitria Rahmayanti ${ }^{1}$, Mahendra ${ }^{2}$, Munandar ${ }^{3}$, Citra Dina Febrina ${ }^{4}$, Endah \\ Anisa Rahma ${ }^{5}$ \\ 124Program Studi Akuakultur, Universitas Teuku Umar \\ Email: fitriarahmayanti@utu.ac.id \\ Email: mahendra@utu.ac.id \\ Email: citradinafebrina@utu.ac.id \\ 35Program Studi Ilmu Kelautan, Universitas Teuku Umar \\ Email: munandar@utu.ac.id \\ Email: endahanisarahma@utu.ac.id
}

\begin{abstract}
Probiotics application in aquaculture sector has been promoted since the government has banned antibiotics application in aquaculture sector. Probiotics are very useful in aquaculture because it can accelerate fish growth, improve fish health, and maintain water quality in good condition. However, there are many fish farmers who do not know the advantages, manufacturing techniques and the application of probiotics to support aquaculture activities. Therefore, we have conducted this community service for fish farmers in Meunasah Sukon Village, Lembah Sabil District, Southwest Aceh Regency. This community service is carried out through counseling by describing the benefits of probiotics, followed by discussions with participants and probiotics practice using natural ingredients that are easily available. The result showed that the level of understanding and knowledge of fish farmers in this village about the benefits of probiotics, how to manufacture and its application were increases after this community service was conducted. The activities of enhancement fish farmer capacities are needed to improve their abilities about information on aquaculture renewable technology.
\end{abstract}

Keywords: Probiotic; Supplement; Fish Farmer

\begin{abstract}
Abstrak
Pemanfaatan probiotik dalam budidaya ikan mulai digalakkan semenjak pemerintah melarang pengguaan antibiotik dalam usaha budidaya perikanan. Probiotik sangat baik digunakan dalam usaha budidaya ikan karena dapat mempercepat pertumbuhan ikan, meningkatkan kesehatan ikan, dan menjaga kualitas air. Namun, masih banyak petani pembudidaya ikan yang belum mengetahui manfaat, teknik pembuatan serta pengaplikasian probiotik untuk mendukung kegiatan budidaya. Dilatarbelakangi oleh hal tersebut, maka dilakukanlah pengabdian kepada masyarakat kepada pembudidaya ikan di Gampong Meunasah Sukon Kecamatan Lembah Sabil Kabupaten Aceh Barat Daya. Pengabdian kepada masyarakat ini dilaksanakan melalui penyuluhan dengan memaparkan manfaat dari probiotik, dilanjutkan diskusi tanya jawab dengan peserta dan praktik langsung pembuatan probiotik dengan menggunakan bahan-bahan alami yang mudah didapatkan. Hasil pengabdian kepada masyarakat ini menunjukkan bahwa tingkat pemahaman dan pengetahuan petani pembudidaya ikan di desa tersebut tentang manfaat probiotik, cara pembuatan serta aplikasinya dalam usaha budidaya perikanan meningkat dengan adanya pengabdian ini. Kegiatan untuk meningkatkan kapasitas pembudidaya sangat diperlukan agar petani pembudidaya dapat terus meningkatkan kemampuannya dan mendapatkan informasi teknologi terkini tentang budidaya ikan.
\end{abstract}

Kata Kunci: Probiotik; Suplemen Tambahan; Petani Pembudidaya 


\section{PENDAHULUAN}

Sektor perikanan merupakan salah satu sektor yang berperan penting bagi perekonomian masyarakat di Provinsi Aceh. Dimana sekitar 55\% masyarakatnya bergantung pada sektor ini, baik langsung maupun tidak. Berdasarkan data produksi perikanan budidaya dari Kementerian Kelautan dan Perikanan Indonesia, total produksi perikanan budidaya di Provinsi Aceh terus mengalami peningkatan setiap tahunnya. Tercatat bahwa total produksi perikanan dari sektor budidaya Provinsi Aceh mencapai lebih dari 104 ton pada tahun 2018 (KKP, 2019).

Total produksi tersebut masih jauh tertinggal dari daerah-daerah lain di Indonesia, seperti di Provinsi Jawa Timur, total produksi untuk sektor perikanan budidaya mencapai lebih dari 510 ton pada tahun 2018 (KKP, 2019). Aceh yang memiliki garis pantai sepanjang $2.310 \mathrm{~km}$ dirasa masih belum maksimal memanfaatan potensi lahan yang tersedia.

Gampong Meunasah Sukon yang terletak di Kecamatan Lembah Sabil Kabupaten Aceh Barat Daya memiliki sumber daya lahan yang masih belum dimanfaatkan secara maksimal. Pada umumnya masyarakat di desa ini berprofesi sebagai petani sawah dan sebagian kecilnya merupakan petani pembudidaya ikan.

Salah satu faktor yang menyebabkan kurangnya minat masyarakat bergelut pada sektor ini adalah karena kurangnya pengetahuan masyarakat tentang prospek di bidang budidaya perikanan. Padahal gampong ini memiliki potensi, baik dari tersedianya lahan yang luas yang dapat dijadikan sebagai media budidaya serta potensi kualitas dan kuantitas air yang memenuhi syarat untuk budidaya. Selain itu, petani pembudidaya ikan di desa ini juga masih rendah tingkat pengetahuannya tentang teknik budidaya yang baik sehingga menghasilkan produksi yang kurang optimal. Kurangnya perhatian dan penyuluhan untuk meningkatkan kapasitas petani pembudidaya ikan dari instansi terkait juga merupakan salah satu penyebab minimnya pengetahuan pembudidaya.

Pada umumnya, kendala yang dihadapi oleh petani pembudidaya ikan yaitu ikan yang dibudidayakan mudah terserang penyakit dan nafsu makan yang rendah sehingga menyebabkan pertumbuhan ikan lambat serta hasil yang panen yang didapatkan tidak optimal. Menurut Irianto (2003), pengaplikasian 
probiotik dalam kegiatan budidaya ikan dapat memperbaiki kualitas air sehingga serangan penyakit dapat diminimalisir.

Kandungan

probiotik

merupakan suplemen yang

mengandung sel-sel

mikroorganisme hidup yang

menguntungkan bagi organisme inang yang mengkonsumsinya.

Menurut Food and Agriculture Organization dan World Health Organization (2001), probiotik diartikan sebagai mikroorganisme hidup yang nonpatogenik yang memberikan efek baik dan menguntungkan bagi organisme inangnya jika dikonsumsi dalam jumlah tertentu.

Berdasarkan hal tersebut, maka kegiatan pengabdian kepada masyarakat perlu dilakukan kepada pembudidaya di gampong tersebut untuk menambah pengetahuan dan meningkatkan kapasitas mereka sebagai pelaku usaha budidaya ikan. Setelah dilaksanakan kegiatan ini, diharapkan petani pembudidaya dapat membuat sendiri probiotik dan mengaplikasikannya untuk kegiatan budidaya agar mereka dapat menjalankan usahanya dengan lebih baik dan mendapatkan hasil yang maksimal.

\section{METODE PELAKSANAAN}

Pengabdian kepada masyarakat dilakukan melalui metode penyuluhan, dengan memaparkan materi tentang pemanfaatan probiotik untuk budidaya ikan dan pelatihan pembuatannya. Melalui kegiatan ini, peserta diberikan beberapa solusi untuk mengatasi berbagai keluhan dan permasalahan yang dialami selama melaksanakan kegiatan budidaya ikan sebagai berikut:

1. Meningkatkan kapasitas petani pembudidaya dengan memberikan penyuluhan tentang teknik budidaya ikan yang benar dan baik.

2. Memberikan informasi tentang pemanfaatan probiotik dan teknik pengaplikasiannya pada budidaya pembesaran ikan untuk meningkatkan hasil panen.

\section{HASIL DAN PEMBAHASAN}

Hasil kegiatan Pengabdian Kepada Masyarakat ini didapakan informasi bahwa pada umumnya tingkat pemahaman peserta tentang teknik budidaya ikan yang benar masih sangat minim. Selain itu, dari hasil diskusi yang dilakukan saat kegiatan ini berlangsung, ada beberapa pemahaman yang masih belum dimiliki oleh peserta dalam hal pembesaran ikan, yaitu:

1. Teknik pemilihan benih unggul. 
2. Teknik pemberian pakan.

3. Informasi tentang nutrisi tambahan (probiotik) yang dibutuhkan oleh ikan untuk mempercepat pertumbuhan dan meningkatkan kesehatannya.

Rendahnya pemahaman dan kemampuan peserta tersebut menyebabkan terkendalanya kegiatan budidaya yang mereka lakukan selama ini. Kegiatan penyuluhan ini mendapat apresiasi dan dukungan oleh peserta (petani pembudidaya di gampong tersebut), yang terlihat dari jumlah peserta yang hadir melebihi target peserta yang direncanakan dan dapat dilihat pada Gambar 1. berikut:

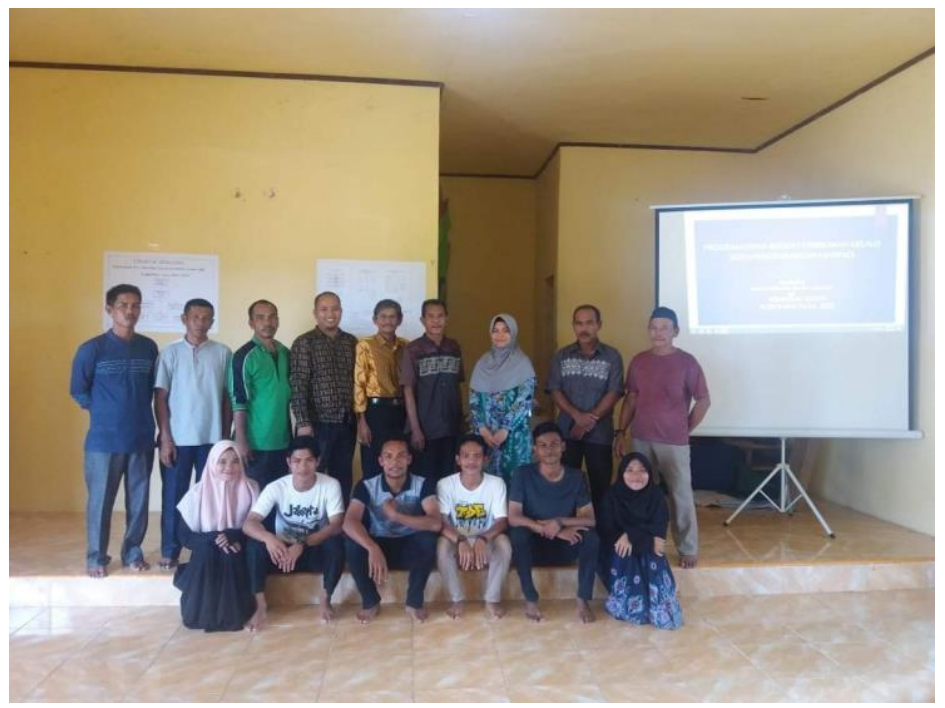

Gambar 1. Pembukaan kegiatan dengan foto bersama peserta.

Melalui kegiatan diskusi selama penyuluhan berlangsung, dapat diketahui beberapa hal yang menjadi kendala peserta saat melaksanakan kegiatan budidaya ikan selama ini yaitu:

1. Tingkat kelangsungan hidup ikan yang rendah.

2. Rendahnya nafsu makan selama masa budidaya.

3. Pertumbuhan yang lambat.

4. Total produksi ikan yang rendah saat masa panen.
Pada kegiatan penyuluhan ini, dijelaskan juga pengertian, manfaat, cara pembuatan dan cara pengaplikasian probiotik untuk kegiatan budidaya ikan. Selain itu, bahan-bahan untuk membuat probiotik juga menggungakan bahan yang murah dan mudah didapatkan serta proses pembuatannya juga sangat mudah.

Kajian tentang probiotik menunjukkan bahwa aplikasi probiotik pada pakan sangat baik diberikan karena dapat 
meningkatkan pertumbuhan dan Kesehatan ikan budidaya. Seperti pernyataan Widanarni et al. (2014), bahwa pemberian probiotik dapat meningkatkan sintasan dan respon imun pada udang vanamei dibandingkan tanpa probiotik. Nutrien yang seimbang akan menghasilkan pertumbuhan yang baik, dan pertumbuhan terjadi apabila ada kelebihan energi bebas setelah energi yang tersedia digunakan untuk pemeliharaan tubuh, metabolisme basal, dan aktivitas.

Selanjutnya, pengaplikasian probiotik juga dapat menjadi alternatif pengendalian untuk mengatasi serangan penyakit karena bakteri probiotik dapat meningkatkan respons imun (Nayak, 2010), memodifikasi komunitas mikroba, memperbaiki nilai nutrisi, memperbaiki respons inang terhadap penyakit, serta memperbaiki kualitas lingkungan (Verschuere et al., 2000).

Selain itu, hasil penelitian dari Dewi dan Evi (2017) menunjukkan bahwa pemberian pakan dengan probiotik pada budidaya ikan lele dapat meningkatkan berat panen dan menekan biaya produksi sehingga dapat meningkatkan keuntungan. Hal ini juga diperkuat oleh pernyataan Erzaneti et al. (2018) bahwa penggunaan probiotik dapat meningkatkan efisiensi pakan nutrisi pakan akan mudah terserap oleh tubuh ikan.

Melalui penyuluhan ini, peserta mendapatkan pengetahuan baru sehingga dapat meningkatkan kapasitasnya sebagai petani pembudidaya ikan. Oleh karena itu, kegiatan pengabdian kepada masyarakat seperti ini sangat baik dilaksanakan secara rutin sehingga permasalahan yang ada pada masyarakat dapat terselesaikan dengan baik. Menurut Darmansyah (2016), Pengembangan masyarakat merupakan kegiatan yang dilakukan bersama komunitas masyarakat dengan cara meningkatkan partisipasi aktif masyarakat dalam rangka memenuhi kebutuhan hidup dan penyelesaikan persoalan-persoalan yang dialami oleh komunitas masyarakat. Selanjutnya (Ihsan, 2002) menyatakan bahwa, kegiatan pengembangan masyarakat dapat berupa peningkatan keterampilan melalui pelatihan peningkatan kemampuan dalam mengolah sumber daya alam.

\section{PENUTUP}

Pelaku usaha di Bidang Budidaya Perikanan membutuhkan kemampuan khusus dalam menjalankan usahanya. Selain modal usaha, ilmu pengetahuan 
dan keahlian di bidang tersebut harus terlebih dahulu dikuasai oleh pelaku usaha (dalam hal ini pembudidaya ikan) sebelum menjalankan usahanya sehingga dapat meminimalisir kegagalan. Selanjutnya, mengikuti perkembangan ilmu pengetahuan terkini juga sangat penting dilakukan oleh para pembudidaya untuk mendapatkan hasil yang optimal.

Melalui penyuluhan tentang teknik budidaya ikan dan pemanfaatan probiotik ini, kemampuan dan kapasitas para petani pembudidaya telah meningkat. Hal ini terlihat dari ketidakmampuan peserta dalam menjawab pertanyaan yang berhubungan dengan teknik budidaya ikan yang diajukan di awal pertemuan, namun dapat dijawab dengan baik di akhir pertemuan. Peserta juga telah mampu membuat probiotik sendiri dengan menggunakan bahan-bahan yang mudah dan murah didapat serta telah mampu mengaplikasikannya pada pakan ikan untuk mengoptimalkan hasil panen.

Kegiatan Pengabdian Kepada Masyarakat melalui metode penyuluhan secara rutin sangat penting dilakukan. Melalui kegiatan tersebut, petani pembudidaya ikan dapat meningkatkan kapasitasnya sebagai pelaku usaha di bidang perikanan sehingga mereka dapat mengembangkan usahanya dengan lebih baik sesuai dengan perkembangan ilmu pengetahuan dan teknologi.

\section{DAFTAR PUSTAKA}

Kementerian Kelautan dan Perikanan. 2019. Statistik Perikanan. Jakarta. Kementerian Kelautan dan Perikanan.

Darmansyah A, Sulistiono, Nugroho T, Supriyono E. 2016. Pemberdayaan Masyarakat Melalui Pengembangan Budidaya Ikan Lele di Desa Balongan, Indramayu, Jawa Barat. Jurnal Agrokreatif IPB. 2(1): 8-16.

Dewi R dan Evi T. 2017. Pemanfaatan Probiotik Komersial Pada Pembesaran Ikan Lele (Clarias gariepinus). Jurnal Riset Akuakultur. 12(3): 275-281.

Erzaneti R, Erlangga, dan Erliza M. 2018. Fortifikasi probiotik dalam pakan untuk meningkatkan pertumbuhan ikan gurami (Osphronemus goramy). Acta Aquatica: Aquatic Sciences Journal. 5(2): 64-68.

FAO/WHO. 2001. Joint FAO/WHO Expert Consultation on Evaluation of 
Health and Nutritional Properties of Probiotics in Food Including Powder Milk with Live Lactic Acid Bacteria. Amerian. Argentina. FAO Press.

Ihsan, YN. 2002. Kajian Pengembangan Budidaya Laut (Pengaruhnya Terhadap Kesejahteraan Responden Pesisir) Studi Kasus Di Kelurahan Pulau Panggang Kab. Seribu [Tesis]. Bogor. Institut Pertanian Bogor.

Irianto, A. 2003. Probiotik Akuakultur. Yogyakarta. Gajah Mada University Press.

Nayak SK. 2010. Probiotics and immunity: a fish perspective. Fish and Shellfish Immunology 29: 2-14.

Verschuere L, Rombaut G, Sorgeloos P, Verstraete W. 2000. Probiotic bacteria as biological control agents in Aquaculture. Microbiolgical and Molecular Biology Review 64: 655-671.

Widanarni, Jeanni IN, dan Sukenda. 2014. Prebiotik, probiotik, dan sinbiotik untuk mengendalikan koinfeksi Vibrio harveyi dan IMNV pada udang vaname. Jurnal Akuakultur Indonesia 13 (1): 11-20. 